\title{
PENGARUH EVALUASI KEBIJAKAN PENDAMPINGAN PENGELOLAAN KEUANGAN DESA DAN KOMPENSASI TERHADAP KINERJA TENAGA FASILITASI PENDAMPING DESA DI KABUPATEN LUMAJANG
}

\author{
ENNY ROSEITA HADI* \\ ANASTASIA MURDYASTUTI \\ ZARAH PUSPITANINGTYAS \\ Jurusan Ilmu Administrasi \\ Fakultas Ilmu Sosial dan Ilmu Politik \\ Universitas Jember \\ *Email: ennyhadi12@gmail.com
}

\begin{abstract}
ABSTRAK
Kinerja pegawai atau kinerja individu merupakan aspek yang berperan penting dalam keberhasilan dan kemajuan organisasi. Pencapain kinerja yang optimal dipengaruhi oleh beberapa aspek, diantaranya adalah evaluasi kebijakan dan kompensasi. Penelitian ini bertujuan untuk mengetahui dan menganalisis pengaruh evaluasi kebijakan pendampingan pengelolaan keuangan desa dan kompensasi terhadap kinerja tenaga fasilitasi pendamping desa di Kabupaten Lumajang, baik secara simultan maupun parsial dengan menggunakan teori kinerja dari Rummler, teori evaluasi kebijakan dari Dunn, serta teori kompensasi dari Sinambela.

Penelitian ini menggunakan jenis penelitian survei kausalitas dengan pendekatan kuantitatif. Populasi berjumlah 222 pendamping desa dengan teknik pengambilan sampel menggunkan teknik Slovin dengan perkiraan taraf kesalahan 5\% dan diperoleh 143 pendamping desa sebagai responden penelitian. Teknik pengumpulan data menggunakan kuesioner, wawancara dan observasi nonpartisipan. Teknik analisis data yang digunakan adalah analisis regresi linear berganda. Hasil uji regresi menunjukkan bahwa baik secara simultan maupun parsial variabel evaluasi kebijakan dan kompensasi berpengaruh positif dan signifikan terhadap kinerja. Berdasarkan hasil penelitian tersebut, hendaknya pemerintah Kabupaten Lumajang tetap mempertahankan dan meningkatkan aspek-aspek yang berkaitan dengan evaluasi kebijakan dan kompensasi guna meningkatkan kinerja pendamping desa.
\end{abstract}

Kata Kunci: Kinerja Pendamping Desa, Evaluasi Kebijakan, Kompensasi 


\section{PENDAHULUAN}

Kinerja organisasi dikerucutkan pada tataran kinerja pegawai atau kinerja individu digadang-gadang sebagai aspek yang berperan penting untuk keberhasilan dan kemajuan organisasi. Terdapat beberapa variabel yang dapat mempengaruhi peningkatan kinerja diantaranya variabel evaluasi kebijakan dan variabel kompensasi. Pertama evaluasi kebijakan, Dunn (2000) mengatakan bahwa evaluasi kebijakan memberikan informasi yang valid dan dapat dipercaya mengenai kinerja; kedua kompensasi, Sinambela (2016) mengatakan bahwa keberhasilan dalam menetapkan kompensasi yang layak akan menentukan bagaimana kualitas sumber daya manusia dalam bekerja.

Tenaga fasilitasi pendamping desa atau yang lebih familiar dengan sebutan pendamping desa merupakan pegawai yang memfasilitasi pengelolaan keuangan desa di Kabupaten Lumajang mulai dari perencanaan sampai dengan pelaporan agar sesuai dengan aturan yang berlaku. Keberadaan pendamping desa yang telah dibekali oleh pedoman maupun aturan terkait diharapkan mampu membantu pemerintah menciptakan tertib administrasi dan peningkatan tata kelola keuangan desa melalui kinerja mereka. Namun wajah pendampingan pengelolaan keuangan desa di Kabupaten Lumajang belum memperlihatkan hasil kinerja yang optimal, terbukti dari data evaluasi lima tahunan mulai tahun 2010 sampai dengan tahun 2014 tren data persentase pelaporan dokumen keuangan desa mengalami penurunan. Hal tersebut dikarenakan pada proses evaluasi masih terdapat kesenjangan yakni tugas yang dilakukan pendamping desa dan perangkat desa belum sesuai tupoksi masing-masing akibat dari belum siapnya perangkat desa melaksanakan tugas sebagai pengelola keuangan desa sehingga tugas tersebut dilaksanakan oleh pendamping desa yang notabene hanya fasilitator desa, kemudian fenomena belum optimalnya kinerja pendamping desa juga dipicu oleh peristiwa penurunan gaji 
pendamping desa, khususnya pada koordinator pendamping yang awal mulanya mendapat gaji sebesar Rp 750.000 menjadi Rp 725.000, memang terlihat nominal penurunnya hanya sedikit, namun memberikan dampak besar pada penurunan kinerja pendamping desa.

\section{TINJAUAN PUSTAKA}

\subsection{Paradigma Ilmu Administrasi}

Paradigma berkaitan erat dengan lokus dan fokus peneitian yang memudahkan penulis dalam memahami arah yang dimaksud pada penelitian yang dilakukan. Paradigma ilmu administrasi menggambarkan hubungan dan perhatian ilmu administrasi negara terhadap ilmu kebijaksanaan yang berfokus pada teori organisasi dengan menggunakan kebijakan publik sebagai analisisnya dan lokus berupa produk-produk normatif yang menggambarkan birokrasi pemerintahan. Thoha (2005:43) menerangkan bahwa "Public policy menjadi kajian utama dan amat penting bagi aministrasi negara, karena sebagai penentu arah umum yang harus ditempuh untuk
Berdasarkan latar belakang di atas, penulis tertarik melakukan penelitian mengenai "Pengaruh Evaluasi Kebijakan Pendampingan Pengelolaan Keuangan Desa dan Kompensasi terhadap Kinerja Tenaga Fasilitasi Pendamping Desa di Kabupaten Lumajang”.

mengatasi isu-isu masyarakat dan digunakan untuk menentukan ruang lingkup permasalahan yang dihadapi oleh pemerintah". Terdapat tiga perspektif dalam administrasi publik yaitu old public administration, new public manajemen dan new public service. Pada penelitian ini penulis memfokuskan pada perspektif organisasi administrasi publik, yang lebih tepatnya pada tataran old public administration yang dijabarkan dalam konsep publik interesnya sebagai sesuatu yang diterjemahkan secara politis dan tercantum dalam aturan, peran pemerintah untuk mengayuh klien dan konstituen menurut hierarkhi administratif (Denhardt dan Denhardt,2003). Konsep publik interes tersebut yang nantinya digunakan sebagai pedoman 
untuk membuat dan melaksanakan kebijakan publik.

\subsection{Kebijakan Publik}

Kebijakan publik diterangkan sebagai keputusan yang dibuat oleh negara, khususnya pemerintah, sebagai strategi untuk merealisasikan tujuan negara yang bersangkutan dengan sekurang-kurangnya mempunyai tujuan yang hendak dicapai melalui sasaran yang spesifik dan perencanaan cara-cara untuk mencapai sasaran dimaksud sehingga mengantarkan masyarakat pada masa awal memasuki masa transisi untuk kemudian menuju pada masyarakat yang dicita-citakan (Syafri 2010:15; Nugroho, 2011:96). Penjelasan tersebut memberi pemahaman kepada kita bahwasannya strategi untuk mencapai masyarakat yang dicita-citakan adalah melalui pengambilan keputusan berupa kebijakan publik dengan tujuan dan sasaran yang tepat. Kita mengenal model linier proses kebijakan dengan enam langka pembentukan kebijakan, yakni:

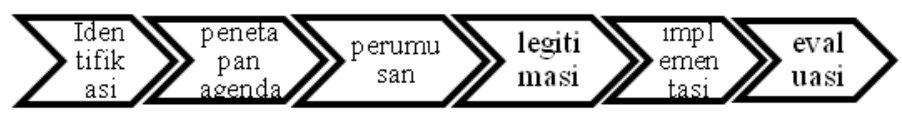

Gambar 1. Model Thomas R. Dye (Sumber : Dye dalam Nugroho, 2015:113)

Dari gambar model proses diaplikasikan, beberapa proses kebijakan tersebut, bisa kita uraikan tersebut kita kenal sebagai proses bahwasannya ketika perumusan politik, kemudian proses selanjutnya kebijakan dimulai dari identifikasi adalah proses implementasi masalah kebijakan, kemudian kebijakan dan evaluasi kebijakan ditetapkan agenda pembuatannya dengan dilanjutkan proses yang kita kenal sebagai proses perumusan kebijakan dan berakhir pada legitimasi kebijakan atau yang sering kita kenal dengan pengesahan kebijakan yang dibuat agar bisa administrasi dalam keseluruhan proses kebijakan. Pada prinsipnya sebuah kebijakan di evaluasi guna mencapai kinerja yang sesuai dengan tujuan kebijakan. 


\subsection{Konsep Kinerja}

Kinerja disebut-sebut sebagai tolok ukur sebuah organisasi dalam prosesnya untuk mencapai tujuan yang telah dirumuskan organisasi. Kinerja organisasi atau lembaga sangat dipengaruhi oleh kinerja individu, karenanya jika kinerja organisasi ingin diperbaiki tentunya kinerja individu perlu diperhatikan (Prawirosentono dalam Sinambela, 2016:484). Individu atau manusia sebagai motor penggerak utama organisasi masuk dalam kategori tangible aset, yang dapat dilihat kinerjanya melalui indikator menurut Rummler dalam Sofo (2003:282) adalah (1) Situasi pekerjaan; (2) Pelaksana kerja; (3) Perilaku; (4). Konsekuensi; (5). Umpan balik dari konsekuensi kepada pelaksana kerja. Bahkan disebutkan pula bahwa manusia merupakan salah satu sumber kekuatan utama dalam organisasi (Ivancevich, 2005:5).

Penulis memahami bahwa keberhasilan penentuan pencapaian tugas terhadap individu akan dapat mengarahkan penetapan kinerja organisasi melalui evaluasi seperti yang diutarakan Dunn (2000:613) bahwa "evaluasi formal bersifat formatif dan sumatif meliputi usaha untuk memantau pencapaian tujuan dan target kinerja setelah suatu kebijakan dilakukan". Hal tersebut sesuai dengan isu evaluasi kebijakan yang dapat dikaji pada tataran kinerja kebijakannya (Nugroho, 2015:262266), oleh Robbins dalam Sinambela (2016:480) ditambahkan bahwa "kinerja individu dalam melakukan sesuatu dengan keahlian tertentu merupakan hasil evaluasi yang dilakukan melalui kriteria-kriteria yang ditetapkan bersama", Oleh karena itu kinerja pegawai sangatlah penting ditelaah oleh organisasi melalui evaluasi kebijakan guna menetapkan pedoman pekerjaan sebagai tolak ukur keberhasilan kinerja. Kinerja pada prosesnya sangat erat kaitannya dengan imbalan balas jasa, hal tersebut diutarakan oleh Sinambela (2016:217) bahwa "pegawai menggunakan pengetahuan, keterampilan, tenaga, waktu serta komitmennya, bukan semata-mata ingin membaktikan atau mengabdikan diri kepada organisasi, melainkan tujuan lain yang ingin 
diraihnya, yaitu mengharapkan imbalan atau balas jasa atas kinerja dan produktivitas kerja yang dihasilkan.

Dari penjelasan di atas penulis memahami bahwa kinerja tidak berdiri sendiri, namun dapat dipengaruhi oleh beberapa yakni dapat dipengaruhi oleh evaluasi kebijakan dan kompensasi pada prosesnya.

\subsection{Konsep Evaluasi Kebijakan}

Evaluasi kebijakan merupakan salah satu aspek yang mempengaruhi kinerja pegawai dalam memberikan sumbangsih kepada kinerja organisasi. Aktivitas evaluasi mempunyai tanggungjawab pada kualitas hidup masyarakat dan kondisi lingkungan serta badanbadan pemerintah, hal tersebut dikarenakan kegiatan evaluasi menyediakan informasi yang mengarah pada isu-isu terkait, kemudian mengembangkan informasi tersebut sesuai waktu dan maksud yang diharapkan untuk proses penetapan kebijakan selanjutnya serta evaluasi digunakan sebagai bentuk komunikasi sebuah kebijakan yang berguna bagi pencapaian tujuan (Rossi,dkk, 2004:11,18). Evaluasi kebijakan dikupas secara mendalam oleh Nugroho (2015:262-266) menjadi tiga isu utama evaluasi, yakni (1) Evaluasi Perumusan Kebijakan; (2) Evaluasi Implementasi Kebijakan; (3) Evaluasi Kinerja Kebijakan, dari ketiga isu tersebut, penulis menekankan penelitian ini pada isu ketiga yakni melakukan penelitian tentang pengaruh evaluasi kebijakan pada tataran kinerja kebijakannya yang dikaitkan dengan kinerja pelaku kebijakan yakni pendamping desa di Kabupaten Lumajang, dengan menggunakan indikator evaluasi kebijakan dari Dunn (2000:610) yakni : (1). Efektivitas; (2). Efisiensi; (3). Kecukupan; (4). Perataan; (5). Responsivitas; (6). Ketepatan.

Pada proses evaluasi kebijakan didalamnya terkandung reward dan punishment kepada pegawai dengan tujuan meningkatkan motivasi dan kecintaan akan pekerjaan yang dilakukan, salah satu faktor yang mempengaruhi kinerja adalah harapanmengenai imbalan (Donnelly dkk dalam Sinambela, 2016:487) 
sehingga penulis memahami bahwa kompensasi juga mempengaruhi kinerja pegawai.

\subsection{Konsep Kompensasi}

Seringnya kita mendengar katakata kompensasi bila berkaitan dengan pekerjaan yang dilakukan, kompensasi juga sering dikaitkan langsung dengan gaji atau tunjangan rutin tiap bulan pegawai hal tersebut belum tepat karena kompensasi lebih komplek dari itu semua, oleh karena itu dibutuhkan penjelasan yang lebih rinci mengenai hal-hal yang berkaitan dengan kompensasi. Saydam (2008:181) yang menyatakan bahwa "kompensasi adalah sebagai bentuk balas jasa perusahaan atau organisasi terhadap pengorbanan waktu, tenaga, dan pikiran yang diberikan mereka (pegawai) kepada perusahaan atau organisasi”. Kompensasi dapat

\section{METODE PENELITIAN}

Jenis penelitian yang digunakan adalah jenis penelitian survei kausalitas dengan pendekatan kuantitatif. Penelitian ini mengambil lokasi di Kabupaten Lumajang berupa gaji, upah, bonus, insentif, dan tunjangan lainnya seperti tunjangan kesehatan, tunjangan hari raya, uang makan, uang cuti dan lain-lain (Hariandja, 2007:244). Organisasi harus menetapkan program-program kompensasi yang didasarkan atas asas keadilan, serta asas kelayakan dan kewajaran dengan memperhatikan aturan yang berlaku dan juga menyesuaikan dengan kemampuan anggaran suatu organisasi. Menurut Sinambela (2016:224) indikator kompensasi meliputi : (1). Finansial Langsung; (2). Finansial Tidak Langsung; (3). Non Finansial.

Kompensasi memiliki pengaruh yang besar dalam penarikan pegawai, motivasi, produktivitas dan tingkat perputaran pegawai. Sehingga tidak dapat dipungkiri bahwa pemberian kompensasi erat kaitannya dengan penentuan kinerja pegawai.

dengan populasi berjumlah 222 pendamping desa dan teknik pengambilan sampel menggunkan teknik Slovin dengan perkiraan taraf kesalahan 5\% sehingga diperoleh 
143 pendamping desa sebagai responden penelitian. Teknik pengumpulan data menggunakan kuesioner, wawancara untuk menguatkan latar belakang dan observasi nonpartisipan.

Instrument dan Skala Pengukuran

Penelitian ini menggunakan intrumen penelitian berupa kuesioner dalam bentuk pernyataan dengan menggunakan skala likert 1-5 sebagai skala pengukuran.

Uji Validitas dan Reliabilitas Instrument Penelitian

1) Uji validitas dengan rumus korelasi product moment pada taraf signifikansi $5 \%$.

2) Uji reliabilitas menggunakan Alpha Cronbach melalui bantuan SPSS.

\section{HASIL PENELITIAN}

\subsection{Uji Validitas}

Hasil uji validitas variabel evaluasi kebijakan $\left(\mathrm{X}_{1}\right)$, variabel kompensasi $\left(\mathrm{X}_{2}\right)$, dan variabel kinerja (Y) adalah valid sehingga indikator yang digunakan pada variabel penelitian ini adalah valid

\section{Metode Analisis Data}

Teknik analisis data yang digunakan adalah analisis regresi linear berganda dengan menggunakan SPSS.

\section{Uji Asumsi Klasik}

1) Uji normalitas;

2) Uji multikolinearitas;

3) Uji heteroskedastisitas.

Analisis Regresi Linear

\section{Berganda}

Bentuk persamaan regresi berganda dalam penelitian ini adalah sebagai berikut:

$$
\mathrm{Y}=\mathrm{a}+\mathrm{b}_{1} \mathrm{X}_{1}+\mathrm{b}_{2} \mathrm{X}_{2}+\mathrm{e} .
$$

\section{Uji Hipotesis}

1) Uji secara simultan (Uji F);

2) Uji parsial (Uji t); dan

3) Koefisien determinasi $\left(R^{2}\right)$. dan layak untuk digunakan sebagai alat ukur pada penelitian.

\subsection{Uji Reliabilitas}

Berdasarkan hasil perhitungan, menunjukkan hasil bahwa seluruh variabel yang digunakan pada penelitian ini bersifat konsisten atau 
reliabel, hal tersebut terlihat dari nilai $\alpha>0,6$ yang artinya reliabel.

\subsection{Uji Asumsi Klasik}

1. Uji Normalitas

Hasil uji normalitas menunjukkan bahwa titik-titik data penyebarannya mengikuti arah garis diagonal, yang artinya model regresi ini telah memenuhi asusmsi normal dari uji normalitas yang digunakan.

2. Uji Multikolinearitas

Berdasarkan hasil uji multikolinearitas, masing-masing nilai VIF kurang dari 10 yang artinya model regresi yang digunakan baik karena tidak terjadi multikolinearitas.

3. Uji Heteroskedastisitas

Hasil uji heteroskedastisitas menunjukkan pola scatterplot yang menyebar baik di atas angka 0 maupun dibawah angka 0 yang menunjukkan tidak adanya pola tertentu yang terbentuk, sehingga model regresi yang digunakan oleh penulis sudah baik karena tidak terjadi heteroskedastisitas.

\subsection{Koefisien}

Determinasi

\section{Berganda $\left(\mathbf{R}^{2}\right)$}

Hasil perhitungan dengan menggunakan SPSS, diperoleh hasil koefisien determinasi $\left(\mathrm{R}^{2}\right)$ sebesar $=$
0,510 yang mempunyai arti bahwa kontribusi yang diberikan oleh variabel evaluasi kebijakan dan kompensasi terhadap variabel kinerja adalah sebesar 51\%, sedangkan untuk sisanya faktor lain yang berkontribusi.

\subsection{Analisis Regresi Linier}

\section{Berganda}

Model persamaan regresi linier berganda pada penelitian ini adalah:

$$
Y=20,649+0,510 X_{1}+0,423
$$

$\mathrm{X}_{2}+\mathrm{e}$

\subsection{Uji secara bersama-sama (Uji} F)

Dari hasil perhitungan persamaan regresi linier berganda diperoleh bahwa $F_{\text {hitung }}=72,742$. Pada taraf signifikansi 5\% diperoleh $\mathrm{F}_{\text {hitung }}>\mathrm{F}_{\text {tabel }}(72,742>3,060)$ sehingga variabel $\mathrm{X}_{1}$ (evaluasi kebijakan) dan $\mathrm{X}_{2} \quad$ (kompensasi) berpengaruh signifikan secara simultan terhadap variabel $\mathrm{Y}$ (kinerja). Berdasarkan pengujian tersebut keputusan yang diambil penulis adalah menolak Ho dan menerima $\mathrm{H}_{3}$ yakni menerima hipotesis yang menyatakan bahwa evaluasi kebijakan pendampingan pengelolaan keuangan desa dan 
kompensasi berpengaruh terhadap kinerja tenaga fasilitasi pendamping desa di Kabupaten Lumajang.

\subsection{Uji Parsial (Uji t)}

1. Pengaruh variabel evaluasi kebijakan $\left(\mathrm{X}_{1}\right)$ terhadap kinerja (Y)

Diperoleh data $t_{\text {hitung }}>t_{\text {tabel }}$ $(7,155>1,977)$ dengan tingkat probabilitas yaitu $0,000<0,05$ sehingga dapat diartikan bahwa variabel evaluasi kebijakan $\left(\mathrm{X}_{1}\right)$ secara parsial berpengaruh signifikan terhadap variabel kinerja (Y). Berdasarkan pengujian tersebut keputusan yang diambil penulis adalah menolak Ho dan menerima $\mathrm{H}_{1}$ yakni menerima hipotesis yang menyatakan bahwa evaluasi kebijakan pendampingan pengelolaan keuangan desa

\section{PEMBAHASAN}

\section{Pengaruh Evaluasi Kebijakan dan Kompensasi terhadap Kinerja}

Penelitian ini mengahasilkan uji regresi linier berganda yang menunjukkan variabel evaluasi kebijakan dan variabel kompensasi memiliki pengaruh positif dan berpengaruh terhadap kinerja tenaga fasilitasi pendamping desa di Kabupaten Lumajang.

2. Pengaruh variabel kompensasi $\left(\mathrm{X}_{2}\right)$ terhadap kinerja $(\mathrm{Y})$

Hasil $t_{\text {hitung }}>t_{\text {tabel }} \quad(5,370$ $>1,977)$, serta pada perhitungan nilai signifikansi juga menunjukkan nilai 0.000 lebih kecil dari 0.05 , sehingga dapat disimpulkan bahwa variabel kompensasi $\left(\mathrm{X}_{2}\right)$ juga secara parsial berpengaruh signifikan terhadap variabel kinerja (Y). Berdasarkan pengujian tersebut keputusan yang diambil penulis adalah menolak Ho dan menerima $\mathrm{H}_{2}$ yakni menerima hipotesis yang menyatakan bahwa kompensasi berpengaruh terhadap kinerja tenaga fasilitasi pendamping desa di Kabupaten Lumajang.

signifikan terhadap kinerja dengan koefisien determinasi sebesar = 0,510, angka tersebut merupakan kontribusi yang diberikan oleh variabel evaluasi kebijakan dan kompensasi terhadap variabel kinerja yakni sebesar $51 \%$, sedangkan untuk sisanya faktor lain yang 
berkontribusi. Hal tersebut

antara variabel evaluasi kebijakan mempunyai arti bahwa semakin berkualitasnya evaluasi kebijakan dan pemberian kompensasi dilakukan pemerintah Kabupaten Lumajang pada proses pendampingan pengelolaan keuangan desa maka kinerja pendamping desa otomatis akan mengalami kenaikan $51 \%$ dari sebelumnya. Angka 51\% tersebut memerlukan pengembangan kembali,sehingga memberikan peluang kepada peneliti yang lain untuk melanjutkan dan memperdalam penelitian ini dengan menggunakan metode penelitian yang lain agar diperoleh temuan yang lebih baik lagi dan saling melengkapi penemuan yang ada. Sehingga dapat menjelasakan secara lebih baik dan mendalam mengenai pendampingan pengelolaan keuangan desa di Kabupaten Lumajang utamanya pada segi evaluasi kebijakan dan kompensasi serta kinerja pendamping desanya.

\section{Pengaruh Evaluasi Kebijakan terhadap Kinerja}

Dari hasil perhitungan dapat dianalisis korelasi secara parsial 
pengelolaan keuangan desa secara jelas sehingga arah dari kinerja pendampingan pengelolaan keuangan menjadi tertib dan meningkat pada tata kelola dan administrasinya.

Indikator efisiensi menyumbangkan $63 \%$ respon dari responden, kebijakan yang memiliki usaha untuk peningkatan tata kelola keuangan serta tertib administrasi dinilai sejalan dengan tujuan pendampingan pengelolaan keuangan desa yang dicita-citakan oleh pemerintah kabupaten Lumajang. Posisi selanjutnya efektivitas cukup tinggi dinilai dapat mempengaruhi kinerja pendamping desa, hal tersebut dikarenakan kebijakan pendampingan yang terukur dapat memberikan standar capaian pekerjaan yang harus dipenuhi oleh pendamping desa dengan maksud pekerjaan yang mereka lakukan dapat terukur, apabila sudah terukur maka suntikan pembinaan dan peningkatan kompetensi serta beban kerja yang layak dapat dilakukan guna peningkatan kinerja.
Kabupaten Lumajang dianggap cukup menghasilkan kebijakan pendampingan yang dapat memecahkan masalah tata kelola dan masalah tertib adminitrasi keuangan di desa. Kemudian indikator dengan nilai terkecil dalam mempengaruhi kinerja adalah indikator perataan sebesar 52\%, alasan yang dapat ditangkap dari respon responden adalah kebijakan pendampingan pengelolaan keuangan desa masih dianggap memiliki celah untuk terlalu membebani kerja pendamping desa, hal tersebut terlihat dari revisi yang terjadi pada aturan Bupati tahun 2010 yang dinilai belum adil mendistribusikan pekerjaan dan manfaatnya, bahkan dinilai tidak memandirikan perangkat desa karena tupoksi pendamping desa yang tertera pada aturan Bupati tahun 2010 nomor 188.45/24/427.1/2010 terkesan seluruh pekerjaan administrasi desa yang mengerjakan adalah pendamping desa, padahal inti dari pencetusan ide adanya pendamping desa adalah menciptakan tertib administrasi keuangan desa dan tata kelola keuangan desa. 
Dari beberapa penjelasan di atas, secara parsial maupun secara simultan diperoleh jawaban secara pasti bahwa variabel evaluasi kebijakan $\left(\mathrm{X}_{1}\right)$ menunjukkan hubungan yang kuat positif dengan variabel kinerja (Y) sebesar $\mathrm{r}=$ 0,639 dan terjadi hubungan yang searah antara variabel evaluasi kebijakan dan kinerja, artinya bila nilai evaluasi kebijakan naik maka tingkat kinerja akan naik secara signifikan dengan 6 (enam) indikator dengan masing-masing nilai respon dari responden sebagai berikut efektifitas 62\%, efisiensi 63\%, kecukupan 59\%, perataan 52\%, responsivitas $67 \%$ dan ketepatan $64 \%$ sebagai ukuran yang mempengaruhi kinerja tenaga fasilitasi pendamping desa di Kabupaten Lumajang.

Beberapa pendapat yang menyebutkan bahwa evaluasi merupakan kegiatan yang menyangkut estimasi atau menilai tingkat kinerja suatu kebijakan dari nilai substansi, implementasi dan dampaknya serta bisa dilakukan apabila kebijakan tersebut sudah berjalan cukup waktu (Subarsono,
2005:119; Winarno, 2014:229), juga diperkuat oleh Riyadi (2009:25) "evaluasi tahunan merupakan evaluasi yang dilaksanakan setiap tahun dalam rentang waktu tertentu terhadap kegiatan prioritas dan outcome pemerintah secara berjangka dan dapat memberikan penilaian atas kinerja pemerintah dalam pembangunan sektoral”. Bahkan didukung oleh hasil penelitian yang menghasilkan bahwa evaluasi kebijakan berpengaruh secara simultan terhadap kinerja pegawai penerima pemberian tambahan penghasilan sebesar 86,50\% (Ameliawati, 2013) dan juga hasil penelitian yang menyebutkan bahwa variabel evaluasi anggaran berpengaruh positif signifikan terhadap variabel kinerja SKPD pemerintah Provinsi Sumatera Utara dengan tingkat kepercayaan angaran sebesar 95\% (Salbiah dan Ridha Rizky, 2012). Sehingga hasil penelitian ini mendukung dan sesuai dengan penelitian sebelumnya yang menyatakan evaluasi kebijakan berpengaruh terhadap kinerja. 
3. Pengaruh

Kompensasi

\section{terhadap Kinerja}

Pada hasil perhitungan dapat dianalisis korelasi secara parsial antara variabel kompensasi $\left(\mathrm{X}_{2}\right)$ dengan tingkat kinerja (Y) diperoleh nilai sebesar $r=0,575$. Nilai ini menunjukkan pengaruh yang cukup positif antara $\left(\mathrm{X}_{2}\right)$ dan $(\mathrm{Y})$. Maksud cukup dan positif di sini adalah terjadi hubungan yang searah yakni pengaruh antara variabel kompensasi dan kinerja, artinya bila nilai kompensasi naik maka tingkat kinerja akan cukup naik secara signifikan. Indikator yang digunakan dalam pengukuran kompensasi ada 3 (tiga) indikator diantaranya indikator finansial langsung, indikator finansial tidak langsung dan indikator non finansial yang merupakan indikator-indikator berpengaruh terhadap kinerja tenaga fasilitasi pendamping desa.

Indikator non finansial menduduki peringkat tertinggi di variabel kompensasi dalam mempengaruhi kinerja yakni respon dari responden sebesar $63 \%$ positif menanggapi bahwa pemberian tugastugas lain dikantor dalam taraf wajar memberikan pengaruh yang positif terhadap peningkatan kinerja pendamping desa, kemudian didukung oleh lingkungan kerja baik kehidupan sosial dikantor maupun lingkungan sekitaran kantor sangat berpengaruh baik terhadap psikologi pendamping desa dalam menyelesaikan tugas-tugas yang menjadi tugas pokok dan fungsi pendamping di desa.

Selanjutnya adalah indikator finansial tidak langung memperoleh respon dari responden sebesar $42 \%$ yakni pendamping desa merasa aman dengan adanya pemberian asuransi kesehatan, kemudian pemberian cuti dan hari libur yang memadai serta fasilitas kantor seperti internet guna kemudahan dalam bekerja mencapai tujuan tertib administrasi dan tertib tata kelolah keuangan desa. Namun respon yang diperoleh masih tergolong rendah, hal tersebut terlihat dari hasil distribusi frekuensi jawaban responden terhadap variabel kompensasi pada tabel 4.6 yang memperlihatkan hasil masih banyak yang merespon tidak setuju pada beberapa poin seperti poin item pemberian cuti dan libur diluar jam 
kerja secara adil respon sebesar $22,4 \%$ menyatakan tidak setuju bila dijadikan ukuran untuk meningkatkan kinerja, dikarenakan seringnya tidak adil dan dilanggar oleh pemegang kebijakan paling dekat dengan pendamping desa yakni kepala desa, kemudian 10,5\% menyatakan tidak setuju terhadap pemberian fasilitas berupa internet gratis untuk meningkatkan kinerja, karena mayoritas dari pendamping desa memberi keterangan mengenai kegiatan yang kurang berhubungan dengan pekerjaan akan dilakukan.

Indikator yang terakhir dengan respon $41 \%$ dari responden adalah indikator finansial langsung berupa gaji, insentif, bonus, pemberian tunjangan diluar gaji. Indikator finansial langsung tergolong dalam respon rendah karena sebesar 34,3\% menyatakan tidak setuju apabila item gaji digunakan sebagai tolok ukur berkinerja, setelah penulis telusuri fenomena yang terjadi dilapangan adalah gaji pendamping desa seringkali mengalami penundaan, karena dampak dari tidak tertibnya pengerjaan SPJ keuangan desa yang mereka dampingi sendiri, kemudian dapat disimpulkan respon penolakan tersebut juga diperkuat oleh penolakan terhadap item bonus yang diterima oleh pendamping desa yang belum sesuai dengan harapan, penolakan tersebut berupa pilihan tidak setuju sebesar $32,2 \%$ yang ternyata di dalangi oleh ketidakpuasan pendamping desa terhadap oknum kepala desa yang notabene harus mengayomi mereka dalam bekerja namun pada kenyataannya banyak penyimpangan sehingga kesejahteraan pendamping desa sering diabaikan oleh desa.

Dari beberapa penjelasan di atas, walaupun beberapa item pertanyaan terdapat jawaban yang kurang positif, namun secara garis besar, variabel kompensasi masih memiliki pengaruh terhadap variabel kinerja baik secara parsial maupun secara simultan diperoleh jawaban secara pasti bahwa variabel kompensasi $\left(\mathrm{X}_{2}\right)$ dengan tingkat kinerja (Y) menunjukkan hubungan yang cukup positif antara $\left(\mathrm{X}_{2}\right)$ dan (Y). Maksud cukup dan positif di sini adalah terjadi hubungan yang searah yakni pengaruh antara variabel kompensasi dan kinerja, artinya bila 
nilai kompensasi naik maka tingkat kinerja akan cukup naik secara signifikan. Indikator yang digunakan dalam pengukuran kompensasi ada 3 (tiga) indikator dengan masingmasing nilai respon dari responden sebagai berikut indikator finansial langsung 41\%, indikator finansial tidak langsung $42 \%$ dan indikator non finansial $63 \%$ sebagai ukuran yang mempengaruhi kinerja tenaga fasilitasi pendamping desa di Kabupaten Lumajang.

Hal tersebut sejalan dengan beberapa pendapat dari peneliti terdahulu mengenai penggambaran hasil kinerja, menurut Sinambela (2016:217) yang menyatakan bahwa "pegawai menggunakan pengetahuan, keterampilan, tenaga, waktu serta komitmennya, bukan semata-mata ingin berbakti atau mengabdikan diri kepada organisasi, melainkan tujuan lain yang ingin diraihnya, yaitu mengharapkan imbalan atau balas jasa atas kinerja dan produktivitas kerja yang dihasilkan". Imbalan yang dimaksudkan tersebut adalah kompensasi yang diterima oleh pegawai atas dasar kontribusi yang diberikan kepada organisasi.

Penolakan atau jawaban negatif merupakan hal yang wajar dalam menyikapi kompensasi, hal tersebut sejalan dengan pendapat Sinambela (2016:221) bahwa "Kompensasi yang baik haruslah seminimal mungkin mengurangi keluhan atau ketidakpuasan yang timbul dari pegawai”. Layak atau tidaknya kompensasi yang diberikan oleh organisasi kepada pegawainya bersifat relatif, karena pada pemberian kompensasi yang wajar berarti besarannya mempertimbangkan faktor-faktor seperti kinerja, pendidikan, jenis pekerjaan, resiko pekerjaan dan yang terpenting adalah dilihat dari tanggungjawab pekerjaannya.

Bahkan didukung oleh hasil penelitian dari Suwati (2013:41-55) yang menyatakan bahwa "Kompensasi berpengaruh positif signifikan terhadap kinerja karyawan PT. Tunas Hijau Samarinda" sehingga peningkatan pemberian kompensasi akan meningkatkan kinerja karyawan. Penelitian selanjutnya juga memberikan hasil 
penguat bahwa variabel kompensasi berpengaruh terhadap kinerja, yakni penelitian dari jurnal oleh Fauzi (2014:172-185) yang menyatakan bahwa "variabel kompensasi finansial berpengaruh positif signifikan terhadap kinerja pegawai

\section{KESIMPULAN DAN SARAN}

\subsection{Kesimpulan}

1. Evaluasi kebijakan pendampingan pengelolaan keuangan desa dan kompensasi berpengaruh secara simultan terhadap kinerja tenaga fasilitasi pendamping desa di Kabupaten Lumajang.

2. Evaluasi kebijakan pendampingan pengelolaan keuangan desa berpengaruh terhadap kinerja tenaga fasilitasi pendamping desa di Kabupaten Lumajang.

3. Kompensasi berpengaruh terhadap kinerja tenaga fasilitasi pendamping desa di Kabupaten Lumajang.

\subsection{Saran}

1. Disarankan untuk memberikan tugas secara sebesar 44\% dibandingkan dengan pengaruh kompensasi non finansial”. Sehingga hasil penelitian ini mendukung dan sesuai dengan penelitian sebelumnya yang menyatakan kompensasi berpengaruh terhadap kinerja. wajar kepada pendamping desa dengan diimbangi pemberian tugas yang cukup krusial kepada perangkat desa yang terlibat dalam pengerjaan administrasi keuangan desa sehingga tupoksi masing-masing dapat terlaksana, serta menaikan gaji secara layak dan membuat aturan tegas dan jelas untuk pemerintah desa mengenai pemberian insentif kepada pendamping desa.

2. Pendamping desa disarankan terus mengembangkan kualitas diri dan selalu proaktif secara sadar terhadap pekerjaannya serta mentaati petunjuk teknis 
pelaksanaan pendampingan

pengelolaan keuangan desa.

3. Temuan penulis mengenai peran aktor desa dan kepentingan pada proses pendampingan pengelolaan

\begin{tabular}{llr} 
keuangan & desa di & luar \\
konteks & penelitian & ini \\
menjadi & bahasan & yang \\
sangat & menarik & untuk \\
dilakukan & \multicolumn{3}{c}{ penelitian } \\
lanjutan. & &
\end{tabular}

\section{DAFTAR PUSTAKA}

Ameliawati, A. 2013. Pengaruh Evaluasi Kebijakan terhadap Kinerja Pegawai Penerima Pemberian Tambahan Penghasilan pada Sekretariat Dinas Peternakan Provinsi Jawa Barat. Ilmu Administrasi. 11(8): $23-33$.

Denhardt, J.V., dan R.B. Denhardt. 2003. The New Public Service: Serving, Not Steering. Southern California : M.E. Sharpe.

Dunn, W.N. 2000. Pengantar Analisis Kebijakan Publik, Edisi kedua. Yogyakarta: Gajah Mada University Press.

Fauzi, U. 2014. Pengaruh Kompensasi terhadap Kinerja Karyawan pada PT. Trakindo Utama Samarinda. Ilmu Administrasi Bisnis. 2(3): 172 185.

Hariandja M.T.E. 2007. Manajemen Sumber Daya Manusia Edisi Revisi, Jakarta : Grasindo

Ivancevich, J.M., R. Konopaske, dan M.T. Matteson. 2007. Perilaku dan Managemen Organisasi, Edisi Ketujuh. Jakarta : Erlangga.

Nugroho, R. 2015. Kebijakan Publik di Negara-Negara Berkembang. Yogyakarta : Pustaka Pelajar
2011. Public Policy Dinamika Kebijakan, Analisis Kebijakan, Manajemen Kebijakan. Jakarta : Elex Media Komputindo.

Riyadi, D. 2009. Manajemen Pedoman Evaluasi Kinerja Pembangunan Sektoral. Jakarta : Bappenas.

Rossi, P.H., M.W. Lipsey, dan H.E. Freeman.2004. Evaluation, A Systematic Approach, Seventh Edition. California : Sage Publications, Inc.

Salbiah dan R. Rizky. 2012. Pengaruh Evaluasi Anggaran terhadap Kinerja Satuan Kerja Perangkat Daerah (SKPD) Pemerintah Provinsi Sumatera Utara. Ekonom. 15(2): 42-52

Saydam,G. 2005. Manajemen Sumber Daya Manusia .Jakarta: Djambatan

Sinambela, L.P.2016. Manajemen Sumber Daya Manusia. Jakarta : Bumi Aksara

Sofo, F. 2003. Pembangunan Sumber Daya Manusia. Surabaya : Airlangga University Press.

Subarsono, A.G. 2005. Analisis Kebijakan Publik, Konsep, Teori dan Aplikasi. Yogyakarta: Pustaka Pelajar. 
Surat Keputusan Bupati Lumajang

Nomor 188.45/08/427.12/2013

Tahun 2013. Koordinator dan Tenaga Fasilitasi

Pendampingan Pengelolaan

Keuangan Desa di Kabupaten

Lumajang Tahun Anggaran 2013. 14 Januari 2013. Lumajang.

Suwati, Y. 2013. Pengaruh

Kompensasi dan Motivasi Kerja terhadap Kinerja Karyawan pada PT. Tunas Hijau Samarinda. Ilmu Administrasi Bisnis. 1(1): $41-45$.

Syafri, W. 2010. Implementasi Kebijakan Publik Dan Etika Profesi Pamong Praja. Jatinangor: Alqaprint.

Thoha, M. 2005. Dimensi-Dimensi Prima Ilmu Administrasi Negara. Jakarta: PT Raja Grafindo Persada

Winarno, B. 2014. Kebijakan Publik Teori, Proses, Dan Studi Kasus. Yogyakarta. CAPS. 